\title{
Improving volumetric productivity of a stable human CAP cell line by bioprocess optimization
}

\author{
Ruth Essers*, Helmut Kewes, Gudrun Schiedner \\ From 22nd European Society for Animal Cell Technology (ESACT) Meeting on Cell Based Technologies \\ Vienna, Austria. 15-18 May 2011
}

\section{Background}

For the production of recombinant proteins, a human cell-derived expression technology can offer significant advantages with respect to protein quality, serum halflife and safety. High volumetric productivity with firstclass quality is the ultimate ambition during process development.

CEVEC's proprietary expression system based on human amniocytes offers significant advantages for the production of complex human proteins and antibodies. The key benefits are the stable and high expression of recombinant proteins with human type posttranslational modifications, the robust growth behaviour with competitive high cell densities and the easy handling in serum free suspension. CAP cells meet all regulatory requirements, they are of non-tumour origin and from an ethically accepted source.

In order to test the performance of CAP cells for the production of very complex proteins, stable $\mathrm{C} 1$-inhibitor expressing CAP cells were developed. $\mathrm{C} 1$-inhibitor is a serine protease inhibitor (serpin) and one of the most heavily glycosylated plasma proteins bearing numerous complex $\mathrm{N}$ - and O-glycans.

\section{Material and methods}

Cells: CAP cells stably expressing C1-inhibitor

Base medium: Protein Expression medium PEM (Gibco \#12661013) containing $4 \mathrm{mmol}^{*} \mathrm{~L}^{-1}$ glutamine (Invitrogen \#25030024)

Supplements: Soy Peptone E110 (OrganoTechnie \#AI885), Glucose (Sigma \#G8679), Valproic acid VPA (Sigma \#4543)

ELISA: In-house C1-inhibitor ELISA using serum derived C1-inhibitor as standard

\footnotetext{
*Correspondence: essers@cevec.com
CEVEC Pharmaceuticals GmbH, Gottfried-Hagen-Str. 62, D-51105 Köln,

* Correspondence: essers@cevec.com
CEVEC Pharmaceuticals GmbH, Gottfried-Hagen-Str. 62, D-51105 Köln, Germany
}

SDS-PAGE/Western Blot: In-house Western Blot for C1-inhibitor

To investigate the influence of different hydrolysates and supplements under controlled conditions we use DASGIP's parallel bioreactor system for cell culture. See table 1 for standard physical process parameters.

\section{Results}

Parental CAP cells were transfected with a plasmid containing expression cassettes for the human $\mathrm{C} 1$-inhibitor driven by the CMV promoter, and a Blasticidine resistance gene for selection. Out of three stable pools, one pool was selected for further single cell cloning by limiting dilution. From initial 251 single cell clones, the best 5 were chosen for further scale-up. Subsequent process development was carried out with one clone showing the best performance in growth and expression.

First we tested the influence of different media supplements shown before to improve cell growth and productivity in CAP cells. Either additional glucose, glutamine, pyruvate, soy peptone, tryptone plus, tryptone or an inhouse mixture of R3-IGF, transferrin, SyntheChol and progesterone were added to the base medium. Cells were cultivated in shake flasks and cell densities, viabilities, metabolites and product concentration were monitored continuously.

Whereas the in-house mixture lead to higher growth rates, the product yields increased upon the addition of glucose (1.2-fold), soy peptone or tryptone (1.5-fold).

Based on these results, we tested additional hydrolysates from cotton seed, wheat gluten, rice protein and soy. Hydrolysates and extra glucose were added to the initial medium and cells were cultivated in shake flasks.

Only medium supplemented with soy peptone II (up to 1.7-fold) and with cotton seed hydrolysate (up to 2.4fold) showed better performance as compared to the control with extra glucose but without hydrolysate. 
Table 1 Standard physical process parameters for DASGIP fermentation

\begin{tabular}{lc}
\hline process parameter & \\
\hline $\mathrm{T}$ & $37^{\circ} \mathrm{C}$ \\
$\mathrm{V}$ & $0.6 \mathrm{~L}$ \\
stirring & marine impeller, $120 \mathrm{rpm}$ \\
aeration & sparging, $0.03 \mathrm{vvm}$ \\
$\mathrm{pH}$ & $7.0\left(\mathrm{CO}_{2} / 0.5 \mathrm{M} \mathrm{NaOH}\right)$ \\
$\mathrm{DO}$ & $40 \%$ (air saturation) \\
starting cell density & $3-5 \mathrm{E} 5 \mathrm{~mL}^{-1}$ \\
\hline
\end{tabular}

In addition to medium supplementation we determined the optimal $\mathrm{pH}$ value for good growth rates, high product quantity and quality. The different batches $(\mathrm{pH}$ unregulated, $\mathrm{pH} 7.0,7.2$ or 7.4) did not differ in maximal product concentrations but in product qualities. This was monitored with SDS-PAGE and western blot. Due to additional specific bands at pH7.2 and pH7.4 either caused by degradation or incomplete glycosylation we decided to continue with $\mathrm{pH} 7.0$ for following process development steps.

Under controlled conditions additional glucose alone or either with soy peptone I, soy peptone II or cotton seed hydrolysate were supplemented to the base medium. Parallel fermentations with different enriched media were started at pH7.0 and cell densities of $3.0^{*} 10^{5} \mathrm{~mL}^{-1}$ under controlled conditions. Cotton seed hydrolysate increased growth, but highest cell density could be observed with soy peptone II or without hydrolysate addition. The maximum product concentration was higher compared to the control in all peptone-fed fermentations. Supplementing soy peptone II or cotton seed hydrolysate almost doubled maximum product concentration.

As a next step, we examined the effect of valproic acid (VPA) on productivity. VPA is a short-chain fatty acid used as well established drug and classified histone deacetylase inhibitor. We set up two cultures with glucose and soy peptone II and two cultures with glucose and cotton seed hydrolysate. In each case, one of the duplicate cultures was additionally supplemented with $4 \mathrm{mmol}^{*} \mathrm{~L}^{-1}$ VPA.

Initial cell densities were $3.5^{*} 10^{5} \mathrm{~mL}^{-1}$ in all four parallel controlled cultures. The addition of VPA was carried out at viable cell densities of $3.0^{*} 10^{6} \mathrm{~mL}^{-1}$. Addition of VPA resulted in 1.6-2.0-fold increase in productivity compared to the corresponding control cultures without VPA

To determine the product quality we performed Western blots with samples from the supernatant of the batches supplemented with VPA. The highest protein quality was obtained from the Soy peptone II-supplemented cultures.

We confirmed the results with 8 (parallel) runs and observed consistent results for cell densities, growth behaviour, product titers, cell specific and volumetric productivities.

\section{Conclusions}

The optimized fed batch strategy starting with $2 \mathrm{~g}^{*} \mathrm{~L}^{-1}$ extra glucose and $4 \mathrm{~g}^{*} \mathrm{~L}^{-1}$ soy peptone II and addition of $4 \mathrm{mmol}^{*} \mathrm{~L}^{-1}$ VPA at a viable cell denstity of $3.5^{*} 10^{6} \mathrm{~mL}^{-1}$ yields 4.3 -fold higher volumetric productivity as

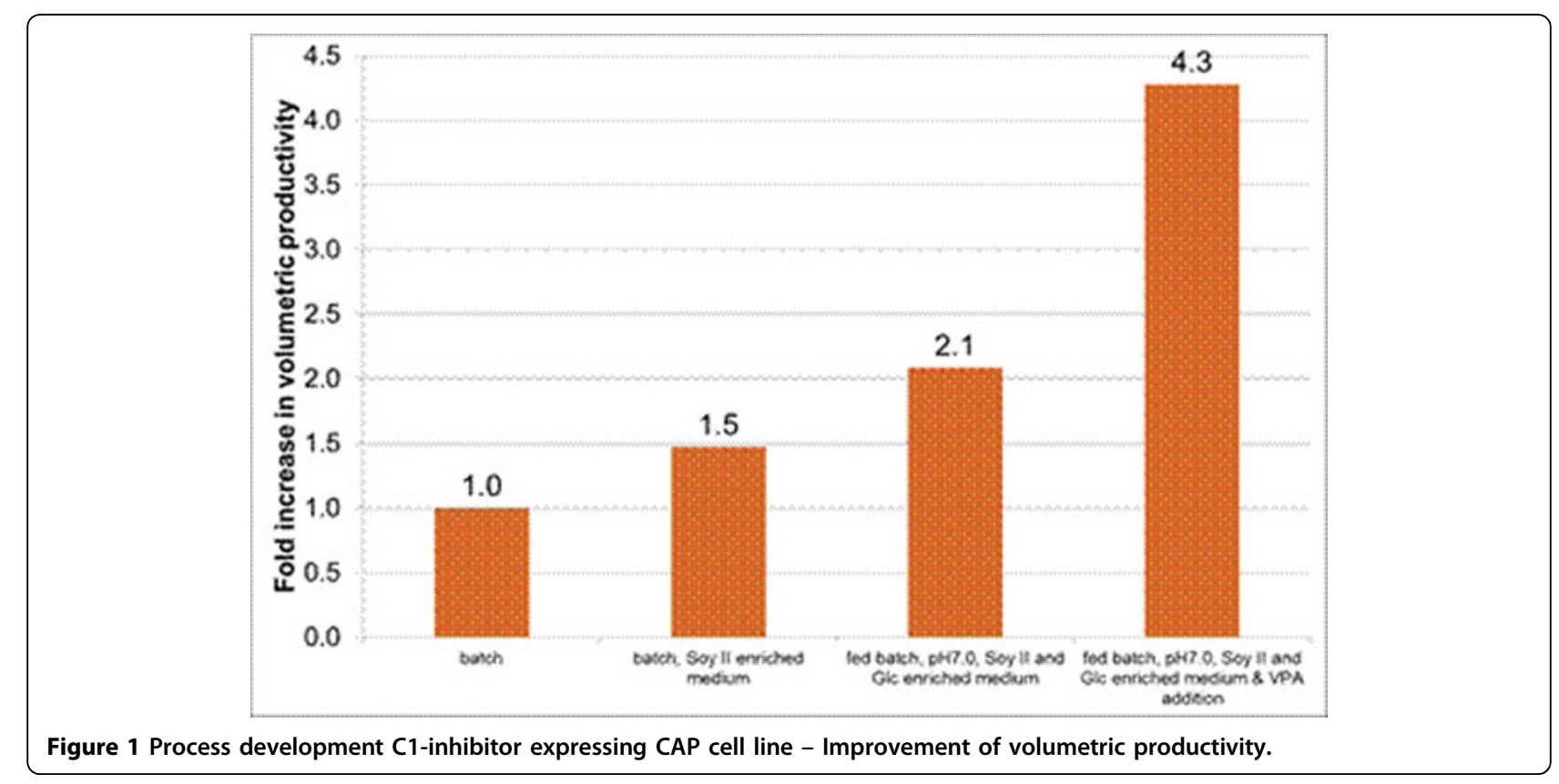


compared to the batch culture (Fig.1). With the optimized fed batch we are able to produce $200-250 \mathrm{mg}^{*} \mathrm{~L}^{-1}$ C1-inhibitor.

Published: 22 November 2011

doi:10.1186/1753-6561-5-S8-P66

Cite this article as: Essers et al:: Improving volumetric productivity of a stable human CAP cell line by bioprocess optimization. BMC Proceedings 2011 5(Suppl 8):P66.

Submit your next manuscript to BioMed Central and take full advantage of:

- Convenient online submission

- Thorough peer review

- No space constraints or color figure charges

- Immediate publication on acceptance

- Inclusion in PubMed, CAS, Scopus and Google Scholar

- Research which is freely available for redistribution

Submit your manuscript at www.biomedcentral.com/submit
C BioMed Central 